\title{
Portrayal of Horror in Stephen King's Revival
}

\author{
R. Kannan, B. Ananda Raghul
}

\begin{abstract}
Horror genre is defined as speculative fiction which is intended to frighten, scare, disgust, or startle its readers by including feelings of horror and terror. Stephen King is considered as one of the foremost writers of Horror fiction. H.P. Lovecraft is an American writer wrote many horror stories. He invented an pseudo-mythology known as the Cthulhu Mythos which focuses on a pantheon of Monstrous deities which inhabits worlds which are not our own. After Lovecraft, many writers tried to imitate his style. But only few got success. One such writer is Stephen King. He closely followed the style of Lovecraft and produced some of the best fictions in the genre of Horror.
\end{abstract}

Keywords: disgust, horror, mythos, startle

\section{INTRODUCTION}

If you ever mention the genre of 'Cosmic Horror' to any person who have read a lot of Horror books ranging from the classics to the modern, you can bet that one person would definitely pop up in his or her mind - H.P. Lovecraft. H.P. Lovecraft is an American author who wrote many tales of science fiction and horror. $\mathrm{He}$ even invented a pseudo-mythology known as the 'Cthulhu Mythos' which focuses on a pantheon of Monstrous deities which inhabits worlds which are not our own. Any person who comes across these beings either accidentally or intentionally, would die in a terrible way or lose their sanity. Only a lucky few would survive the terrible encounter. After Lovecraft's death, various horror writers utilized these elements and wrote pastiches based on his tales. However, there were some writers who did not merely imitate Lovecraft's style but also developed ideas and styles of their own. One of these brilliant Horror story writers is Stephen King. Stephen King is known for his acclaimed novels such as Carrie (1974), The Shining (1977) and IT (1986). He also wrote some Lovecraftian tales such as Crouch End (1980) and Jerusalem's Lot (1978).

\section{LITERATURE SURVEY}

There are other studies which position King's fiction in a variety of different contexts with most choosing to situate King's work within a specifically gothic context.

Revised Manuscript Received on December 29, 2019.

R. Kannan*, Department of English, Kalasalingam Academy of Research and Education, Krishnankovil, Virudunagar, Tamilnadu, India. Email: kannanraman1975@gmail.com

B. Ananda Raghul, M.Phil Research Scholar, Department of English, Kalasalingam Academy of Research and Education, Krishnankovil, Virudunagar, Tamilnadu, India. Email: kannanraman1975@gmail.com
This is evident in works such as Joseph Grixti's chapter 'Language, Modes of Seeing, and the Magic - The Covenant of Stephen King' in Terrors of Uncertainty: the Cultural Contexts of

Horror Fiction (1989) in which he recognizes that King 'writes in a gripping and calculatedly popular manner' (Grixti, 1989, p. 46) before asserting the "mixture of "camp" taste and concern for the genre maintaining or achieving some sort of intellectual or "cultured" respectability' that King displays, 'is symptomatic of the ambiguous standing of contemporary horror fiction in general and of King's approach and attitudes in particular' (Grixti, 1989, p. 47). While Grixti makes a point of illuminating this 'mixture' his attention remains on King's contribution to the horror genre.

Another example is present in David Punter's article 'Problems of Recollection and Construction: Stephen King' in Modern Gothic: A Reader (1996) in which he concentrates his analysis on King's 'hidden master narrative' (Punter, 1996, p. 121). He argues that this 'master narrative' 'hinges psychologically on a swing between two different world-views' (Punter, 1996, p. 121). However, while Punter attributes these two 'world views' to 'the child and the adult' (Punter, 1996, p. 121), I contend that the master narrative present in King's work stems from his preoccupation with the high/low dialectic. James Egan's 'Sacral Parody in the Fiction of Stephen King' (1989) similarly adopts a decidedly gothic perspective stressing that 'Stephen King's habits as a Gothicist have been much discussed, but his consistent development of Gothicism's parodic tendencies and the direction of his parody deserve more attention' (Egan, 1989, pp. 125-126).

\section{THEME OF HORROR IN REVIVAL}

The most terrific book that could be highly and appropriately considered as cosmic Horror Fiction is Stephen King's novel Revival (2014). Revival not only speaks about what would happen after death but also about Loss of Innocence, Tragedy, Family, etc. It is also a coming-of-Age story. The narrator of the novel is Jamie Morton whose life with his family is happy and peaceful. However, one day, he faces a shadow that would haunt him till his death. This shadow happens to be Charles Jacobs, the newly ordained Minister of the Methodist Church in Harlow, Maine where Jamie and his family live. Both Jamie and Jacobs liked each other, ever since they met each other in the beginning. Aside from preaching, Jacobs also has a deep interest in electricity and invents some gadgets which he shows to Jamie. 
Jacobs even cured Jamie's brother Conrad who lost his voice in an accident with a strange device. Life goes on peacefully, until tragedy enters Charles beloved wife Patsy and his son Mortie die in a terrible car accident which shocks and traumatizes him. One day, in a church meeting, he gives a blasphemous speech about religion and renounces his faith in god in front of a shocked audience. This gets him fired from his job and he leaves the town alone after talking to Jamie. Few years later, Jamie who became a guitarist for a rock and roll band meets Charles Jacobs once again in a carnival. Jacobs works there as an illusionist, entertaining the audience with his strange gadgets which runs on secret electricity. He recognizes Jamie and helps him recover from his addiction to drugs using a strange device that runs on the 'secret Electricity' which Jacobs harnesses for some unknown purposes. However, after his recovery, Jamie experiences strange side-effects such as sleep-walking, nightmares and the uncontrollable urge to stab his own hand with a sharp object. Another few years later, Jamie hears that Charles became a faith-healer using his strange devices to cure people who suffer from various physical disabilities. Jamie begins to suspect something fishy about Jacobs when he discovers that those who were cured by Jacobs were suffering from strange side effects like Jamie's. Some of them became mentally unstable, while others killed themselves after killing some of their loved ones. Hearing these incidents, Jamie decides to confront Jacobs for one, last time and also to know Jacobs motives behind his sinister actions.

Now one might ask what kind of connection is there between this novel and the cosmic horror genre. The answer is, it has a lot of connections in the final two chapters, and Jacobs reveals that the purpose behind his sinister doings was to discover what happens after death. Even though Jamie wants to stop Jacobs from fulfilling his ambition, he cannot do so because Jacobs cured his girl friend Astrid of her cancer. Due to this, Jamie reluctantly serves Jacobs even though he does not want to be a part of it. Jacobs uses a corpse of a woman named Mary Fay and Jamie to open the gate that leads to the world beyond death by linking them with his 'secret' electricity. Unfortunately, they did not anticipate the terror that was waiting for them. Instead of Heaven, they discover a dark world where dead human beings are ruled by powerful, insane, supernatural entities known as the "Great Ones." The Great Ones resemble more like Lovecraft's old ones, the pantheon of monstrous deities mentioned before. Jamie realizes that Heaven is a delusion and there is no salvation for human beings after seeing his sister and Charles Jacob's wife and son among the undead. Only Horror awaits them. One of the Great Ones, a monstrous entity named Mother notices Jamie and Jacobs peeping through the 'portal' and arrives into the normal world through the same 'portal' to get rid of both of them. Jacobs dies of a heart stroke after being shocked of Mother's appearance. Luckily, Jamie escapes from Mother's clutches by shooting the portal -the corpse of Mary Fay - with a gun. In the last chapter, Jamie now a pretty old man is living peacefully in a mental asylum in Hawaii. He acknowledges that life, in spite of its hardships or troubles, is more preferable than the horror that waits for mankind after Death. He also remembers clearly what Mother said to Charles Jacobs, "No Death, No Sleep, No Rest."

\section{CONCLUSION}

The message of this novel is consistent with Lovecraft's philosophy of cosmicism which states that mankind is totally irrelevant in the grand schemes of an indifferent universe and that he is not so valuable or special. Also the belief in a benevolent and superior force like God is nothing but a delusion held by ignorant mankind. The novel ends with Jamie thinking about the terrible fate that awaits him after death the scene in which Jamie conjures up a vision of the after-life is reminiscent of Mary Shelly's Frankenstein and Arthur Machen's The Great God Pan. Besides Lovecraft, Stephen King also cites Arthur Machen's Novella The Great God Pan as an inspiration for this novel. Thus Stephen King's novel Revival deserves to be added rightfully into the list of books that are considered as Cosmic Horror Fiction.

\section{REFERENCES}

1. Alex E. Alexander, "Stephen King's Carrie: A Universal Fairytale", Journal of Popular Culture 13, 1979, pp.282-88.

Stephen King. "Revival.” London, UK. 2015.

3. Arthur Pais, "Horror at its Sickening Best, "Society, Bombay: Lana Publishing Co., December 1987, pp. 83-85.

4. Tim Underwood "Kingdom of Fear: The World of and Stephen Kinq" Miller, Chuck, eds New York: New American Library, Signet, 1986.

5. Douglas E. Winter, "The Readers' Guide to Stephen Kinq.” New York: Starmont, 1982.

\section{AUTHORS PROFILE}

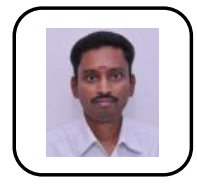

Dr.R.Kannan is an Associate Professor of English in Kalasalingam Academy of Research and Education. He completed his Ph.D. in 2009. He has a teaching experience of over fourteen years. Under his guidance, one awarded his Doctorate, fourteen scholars completed their M.Phil dissertation. At present, under his supervision, four scholars are pursuing their Ph.D. He has published two papers in Scopus Indexed Journal, fourteen papers in UGC listed and other journals and also presented papers in both National and International conferences. He was a Doctoral Committee Member in VIT, Vellore. He is the journal reviewer of Humanities, Online International Journal, Switzerland. He is the BEC Centre Exams Manager and Speaking Examiner for BEC in Kalasalingam Academy of Research and Education.

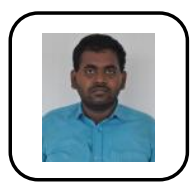

B.Ananda Raghul formerly M.Phil. Scholar, Department of English, Kalasalingam Academy of Research and Education, interested in reading books and he has a special interest in horror tales and stories. He has done his M.Phil Research on Stephen King. 